\title{
The Personal Resources Influence on Malaysian Graduates' Career Adaptability via Mentoring as a Mediator
}

Faiza binti Omar, Abdul Rahman bin Abdul Rahim, Nor Intan Adha Hafit

To Link this Article: http://dx.doi.org/10.6007/IJARBSS/v12-i1/12024 DOI:10.6007/IJARBSS/v12-i1/12024

Received: 11 November 2021, Revised: 16 December 2021, Accepted: 30 December 2021

Published Online: 23 January 2022

In-Text Citation: (Omar et al., 2022)

To Cite this Article: Omar, F. binti, Rahim, A. R. bin A., \& Hafit, N. I. A. (2022). The Personal Resources Influence on Malaysian Graduates' Career Adaptability via Mentoring as a Mediator. International Journal of Academic Research in Business and Social Sciences, 12(1), 1807-1823.

Copyright: (c) 2022 The Author(s)

Published by Human Resource Management Academic Research Society (www.hrmars.com) This article is published under the Creative Commons Attribution (CC BY 4.0) license. Anyone may reproduce, distribute, translate and create derivative works of this article (for both commercial and non0-commercial purposes), subject to full attribution to the original publication and authors. The full terms of this license may be seen at: http://creativecommons.org/licences/by/4.0/legalcode

Vol. 12, No. 1, 2022, Pg. 1807- 1823

Full Terms \& Conditions of access and use can be found at http://hrmars.com/index.php/pages/detail/publication-ethics 


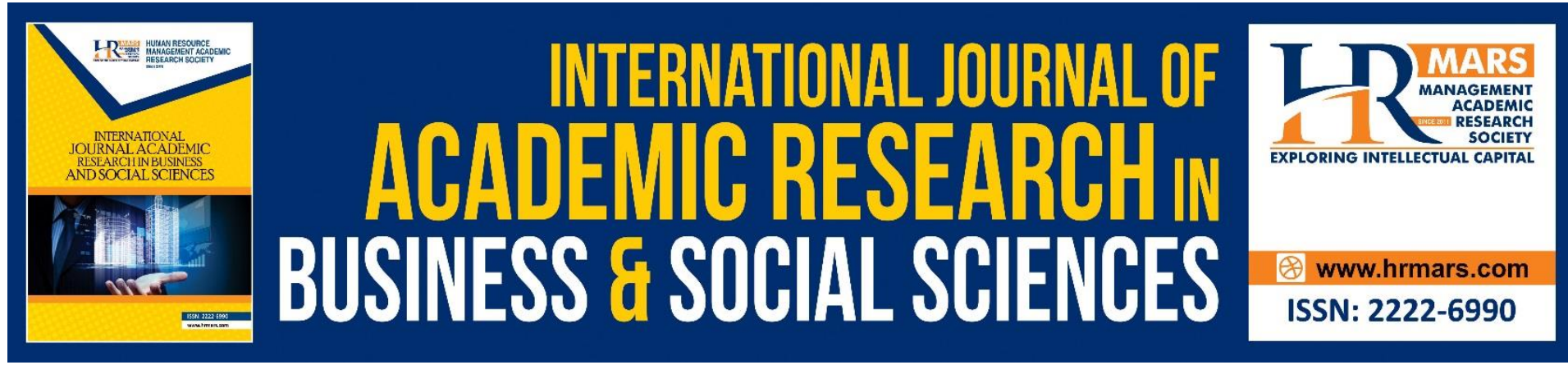

\title{
The Personal Resources Influence on Malaysian Graduates' Career Adaptability via Mentoring as a Mediator
}

\author{
Faiza binti Omar \\ Faculty of Business Management, University Teknology MARA (UiTM), 40450, Shah Alam, \\ Selangor Darul Ehsan, Malaysia \\ Email: faizaomar@gmail.com
}

\author{
Abdul Rahman bin Abdul Rahim (Assoc. Prof. Dr) \\ Arshad Ayub Graduate Business School, University Teknology MARA (UiTM), 40450, \\ Shah Alam, Selangor Darul Ehsan, Malaysia \\ Email: aman@uitm.edu.my \\ Nor Intan Adha Hafit (Dr.) \\ Faculty of Business Management, University Teknology MARA (UiTM), 40450, Shah \\ Alam, Selangor Darul Ehsan, Malaysia \\ Email: intan520@uitm.edu.my
}

\begin{abstract}
This paper was designed to explore critical factors of personal resources (psychological resources, emotional intelligence, and self-perceived competencies) influencing graduates' career adaptability. This paper is derived from personal resources and career adaptability studies that employed the career construction theory. The relevance of career adaptability has risen significantly in the workplace due to the business environment's demands. Thus, workforces have to develop their self-strengths in knowledge, skills, and relevant competencies in meeting industrial demand. Furthermore, the necessity of career adaptability enables the workforce to thrive in facing unpredictable changes, succeed in their career journey, and remain competitive in the challenging labour market. Since the career adaptability topic is being studied continuously worldwide, it is still limited to Malaysian graduates' perspectives. Hence, in line with the topic development, this paper promotes a better understanding of career adaptability among new employment groups to be conscious of and prepared for future unanticipated changes in the working world.
\end{abstract}

Keywords: Career Adaptability, Psychological Resources, Emotional Intelligence, SelfPerceived Competencies 


\section{Introduction}

The tremendous organisational changes due to external forces such as political, economic, social, technological, legal, and environmental force organisational members to quickly adapt to sustainability. That is, organisations are looking for adaptable, flexible individuals, and possess additional soft and hard skills (Harvard Business Review, 2019; Shamsuddin \& Christina, 2020). Simultaneously, the external forces impact organisation structure and management. That is demonstrated in today's organisations has gotten flatter (TalentCorp Malaysia, 2017). The traditional career movement is obsolete (Ismail, 2017); individuals are no longer dependent on the organisation for career advancement. Thus, to be relevant in the labour market, the workforce must be better prepared to deal with unanticipated circumstances. Individuals with abilities and skills find the ideal workplace to establish a career life path (Shabeer et al., 2019; Shen et al., 2018). Career mobility is accepted and practiced in today's dynamic workplace culture, enabling individuals to strategize and maintain their values (Le et al., 2019).

The concept of career adaptability enables an individual to be ready, adjust, be prepared for anticipated situations (Lumanta, 2020; McKenna, 2021). Foresighted people may prepare ahead to avoid being in an uncomfortable or stressful circumstance for an extended length of time. Participation in self-development programs would prepare the individual to be marketable ready by equipping themselves with current knowledge and skills demand (Chartered Institute of Personnel and Development, 2019; PwC Malaysia, 2021b).

As Malaysia aspires to become a high-income and developed country, the 12th Malaysia Plan emphasises the importance of national talents being prepared, eager to embrace cutting-edge technology and innovation over the next five years (Mustapa, 2020). The priority of enhancing the quality of national education, investment in human capital, and social welfare protection will lead to the achievement of the aspiration (World Bank, 2021). Therefore, personal resources enhancement could influence an individual's career adaptability (Ilyana \& Raba'ah, 2020; Le et al., 2019). However, the issue of youth unemployment is constantly worrying in Malaysia's dynamic labour market (Zuraini, 2020). In 2020 , the rate of unemployment among graduates, considered as those who have completed their education and are seeking work was 15.6 percent, or 40,550 out of 260,701 people (Ministry of Higher Education, 2020). The disparity in employment opportunities and labour shortages (Ministry of Human Resources, 2020) compel graduates to possess critical and technical skills in addition to working experience turns, which becomes a barrier for graduates to secure employment (Chartered Institute of Personnel and Development, 2019; Harvard Business Review, 2019). In addition to employers' demand for high cognitive intelligence, adaptability, self-motivation, readiness to learn (Le et al., 2019), flexibility toward digital revolutions, and receptiveness to changing work environments (PwC Malaysia, 2021) are other barriers to employment for graduates. The disequilibrium and weak labour market make it difficult for graduates to obtain positions commensurate with their education level (Shamsuddin, 2020).

In consonance with that, Malaysian graduates' battle to secure employment continues, deteriorating the situation Malaysian employers' assertions that graduates lack in-demand skills, are incapable of impressing the employers and lack relevant knowledge, skills, and abilities (Dian \& Zaidi, 2016; Nooriah \& Zakiyah, 2015; Shamsuddin, 2020). They asserted that the graduates hired are not the best candidates available; rather, the graduates are only qualified to be an employee on an average level (Cheong et al., 2016). Some (Abdul Wahed, 2017; Mahathir \& Vethasalam, 2021) argued that the Malaysian academic curriculum appears 
to be incompatible with industry requirements, resulting in lower-quality graduates. Thereby, graduates encountered difficulties in the first job, felt unprepared for the joined industry, received unsupportive leadership, lacked mentorship, and encountered work with difficult superiors (Monster.Inc, 2020). Job demand, role conflicts, and role ambiguity render them incapable of overcoming task difficulties (Heang et al., 2019). This unsettling working environment and organisational culture's challenges has resulted in job dissatisfaction, occupational stress, and intention to leave (Edwin, 2020; Heang et al., 2019; Kashmoola et al., 2017; Mumu et al., 2021; Puteh et al., 2015; Rozman et al., 2019). The unfit situations influence graduates seeking new job opportunities during their first year of employment, they just stay in one organisation for less than two years and change jobs twice in five years (Puteh et al., 2015). Presumably, graduates are having difficulty adjusting to the workforce, resulting in career indecision, job satisfaction, job quality, and difficulty achieving career success.

The following questions are posed as a result of these circumstances: Why do graduates lack in-demand skills? Why are they unable to convince employers in the hiring process? Were they unprepared prior to graduation? Are they aware of the labour market challenges? And how viable are they for future jobs? In conjunction with that, this paper outlines the importance of a person's career adaptability: to be readily prepared, cope with unprecedented events, and adjust to any circumstances to be relevant in the future (Savickas, 2013). Even though there is an abundance of studies on career adaptability being debated, most of the focus groups concerned adolescents, high school, and tertiary students (Fawehinmi \& Yahya, 2018; Francisco \& Castano, 2020; Green et al., 2020; Merino-Tejedor et al., 2018; Nilforooshan \& Salimi, 2016; Shin \& Lee, 2019; Son, 2018). Considering the graduate's skills gap and the lack of graduates' capabilities, this paper conceptualises the personal resources from the perspective of psychological resources, emotional intelligence, and self-perceived competencies' influence on career adaptability.

In responding to a study by Nooriah \& Zakiyah, 2015) employability depends on individual factors, the labour market, and organisational practice. Study result has shown that the final year students have no ideas on their future employment, are unprepared for career needs, and doesn't have any strategies to compete in this challenging labor market. Thus, this paper illustrates the personal strength in assisting graduates in thriving in the labour market and serves as a wake-up call to stakeholders such as educational institutions and industrial practitioners to be aligned with the future workforce's working conditions and environmental demands.

\section{Career Adaptability}

Career adaptability refers to the ability to adjust to changes in work and working conditions and the predictable tasks of preparing for and participating in the work role (Savickas \& Savickas, 2016). The concept is associated with psychosocial resources that involve adapting to changing tasks, engaging in ongoing self-learning, and self-regulating. Career adaptability is vital competency in these current unexpected demands by employers and uncertain career prospects (Guan et al., 2016). The combination of a person's identity and adaptability guides the individual in determining when and how to change. In addition, impressive attitudes, behaviour, and well-developed competencies enable individuals to adapt to diverse environments easily (Savickas \& Porfeli, 2012). Employees with high levels of career adaptability can plan for future career tasks (concern), take responsibility for their career development (control), investigate potential future selves and career opportunities (curiosity), and have faith in their ability to solve career-related problems (confidence). Career 
adaptability, indeed, is bounded by the social, institutional, and cultural context of a multidimensional structure of concern, control, curiosity, and confidence to support and assist the individual to react by strengthening their vocational behaviour toward the unanticipated change (Savickas \& Porfeli, 2012).

Thus, with the concerns about graduate unemployment and skill gaps, graduates must have career adaptability and industrial demand skills to succeed in their employment success (Haibo et al., 2018). To achieve career success, graduates must have a long-term career plan, be competitive and relevant in the labour market, and be willing to develop their selfcompetence and value. Encouraging career adaptability among graduates would benefit them to secure suitable jobs, assist in work transition, increase employability, and achieve employment quality (Chen et al., 2020; Fawehinmi \& Yahya, 2018; Ibrahim et al., 2021; Monteiro et al., 2019; Yen et al., 2019). Thus, graduates would benefit in the long run from an understanding of personal factors, particularly psychological resources, emotional intelligence, and self-perceived competencies.

\section{The Influence of Personal Resources on Career Adaptability}

Personal resources refer to unique individual characteristics, strengths, and abilities to strive and understand the environment to act accordingly toward the situation(Zia et al., 2020). As the environment is unanticipated, individuals must be concerned about their capabilities through strengthening their control to enable them to explore possible future scenarios (Savickas \& Porfeli, 2012). Hence, individuals' distinctive characteristics enable them to interact with their environment, but the process of connection necessitates the development of specific competencies to deal with unexpected situations (llyana \& Siti Raba'ah, 2020).

The workplace challenges require an individual to take a holistic view of his or her surroundings and to be prepared for unforeseeable events. Individuals' strength is critical for thriving in challenging work environments(Jiang, 2017; Le et al., 2019). To enable an individual for an unprecedented work environment, the concept of person-environment fit should be applied. Where the individual must assimilate into their environment through selfawareness, belief in their capability, and strength. Moreover, Malaysian employer's expectation toward graduates to posses' values and personalities (willingness to learn, openness, positive outlook, diversity of interest beyond job responsibilities), as well as the necessary knowledge and skills for the work environment, and competencies that can be applied to specific situations (Cheong et al., 2016). As a result, it is critical for graduates to focus on strengthening their personal resources to develop the career adaptability necessary to deal with and prepare for unanticipated challenges in the future. Thus, this paper emphasises the importance of personal resources within the contexts of psychology (individual internal spirit to believe in themselves for the future), emotion (to react appropriately to the environment), and competency awareness (to be prepared with their capability to strive in the challenging environment) in influencing graduates' career adaptability.

\section{Psychological Resources Influence Career Adaptability}

Psychological resources refer to the development of characteristics by having confidence (efficacy), preserving toward goals (hope), positive attributes (optimism), and bouncing back even after failure (resilience) (Luthans et al., 2007). Additionally, those components will inspire a motivational disposition for completing tasks and goals, a person's capacity to adjust 
to change, even in the face of adversity, and capabilities in strategizing to overcome the obstacles. Some (Bandura, 1994; Othman et al., 2018) view psychological resources as an individual's beliefs and trust in future outcomes, as well as perceived cognitive and affective resources that enable an individual to act and believe the challenges will be beneficial in the long run.

While psychological resources as a proximate predictor to personal resources indicate a positive relationship with career adaptability (Othman et al., 2018; Safavi \& Bouzari, 2019), the study of psychological resources indicates individuals with vital psychological resources (efficacy, hope, optimism, and resilience) are able to increase the capacity for adaptation, are capable of coping with future turbulent changes, more adaptable on the job and career context (Buyukgoze-Kavas, 2016; Coetzee et al., 2017; Othman et al., 2018; Safavi \& Karatepe, 2018). Consequently, psychological resources also affect minimizing job stress (Shabir et al., 2014), employee well-being (Avey et al., 2010), work engagement(Coetzee et al., 2017) implicitly led to career adaptability (Fiori et al., 2015; Urbanaviciute et al., 2019; Yang et al., 2019). Moreover, argued by Fang et al (2018); Santilli et al., (2017) characteristics of hope and optimism are positive attitudes that mediate career adaptability that are able to be led for the future outcome and gain life satisfaction. Through hope and optimism, individuals acquire diverse interests in self-resilience and efficacy that would develop psychological resources that directly affect career adaptability.

Thus, to achieve career adaptability, graduates should increase their self-efficacy by developing self-belief, having hope to overcome the unexpected of a changing world, being an optimist with all available opportunities, and developing self-reliance by enabling them to bounce back after failing to complete a task or meet task expectations. Through these facets, graduates can advance their future beliefs, maintain an open mind, and set positive goals for coping with the environment. Psychological resources as a means of intrinsic essence development could assist graduates in standing on their convictions, thereby preparing them to meet industrial demand. Thus, this paper makes the following hypothesis:

$\mathrm{H} 1$ : There is an indirect influence of psychological resources (efficacy, hope, optimism, and resilience) on career adaptability

\section{Emotional Intelligence Influences Career Adaptability}

In the interest of an unpredictable working environment and condition, emotional intelligence is crucial for an individual's ability to adapt to uncertain circumstances (Jameson et al., 2016; MichaelPage, 2019; Parmentier et al., 2019). Additionally, emotional intelligence refers to an individual's capacity for self-control when it comes to interacting with others and sustaining and developing social relationships (Serrat, 2017). Emotional intelligence is also a set of interrelated abilities possessed by the individual to deal with emotions (Wong \& Law, 2002), an ability to generate feelings and facilitate thoughts of others and oneself (Salovey \& Mayer, 1990) enable an individual to control his as well as group members emotion. Hence, this paper adopts Wong \& Law (2002) four-dimensional model of emotional intelligence: appraisal and expression of emotion, appraisal, recognition of emotion in others, regulation of emotion in self, and use of emotion to facilitate performance in measuring emotional intelligence and influencing career adaptability.

The debate over the relationship between emotional intelligence and career adaptability continues to arise (Coetzee \& Harry, 2014; Eryilmaz et al., 2020; Ilyana \& Siti Raba'ah, 2020; Mittal, 2020; Parmentier et al., 2019; Sony \& Mekoth, 2016). Harry (2017) argued the fact that emotional intelligence would help people deal with emotions in the 
workplace, thus reducing occupational stress and enhancing psychological well-being. An individual with high emotional intelligence is concerned with organisational culture, job duties, competitiveness, self-control, and enhancing harmonisation (Serrat, 2017). They are also being categorised as better employees because they are able to concentrate and complete the tasks even though their skills are being underutilised (Wong \& Law, 2002).

Ability to regulate emotional intelligence in people's lives, individuals can endure difficulties, specifically in once uncertain situations (Mittal, 2020). Even more, high emotional intelligence affects decision making and participation (Asif Kiyani et al., 2011), job satisfaction, organisational commitment, work engagement, minimising stress, and willingness to perform (Navas \& Vijayakumar, 2018). Even though the individual facing a work-related difficulty has an issue to be resolved, those with high levels of emotional intelligence will be better equipped to deal with the uncertainty associated with job challenges, which has resulted in career adaptability.

Concerning newly employed graduates, who have less maturity (Abd Rahman et al., 2020), especially in job experience, they are required to have better control of their emotions in adapting to working challenges. Some (Anastasiou, 2020; Shipley et al., 2010) argued that emotional intelligence is not significant with age. However, people's lives continue to grow, and their age through life experiences affect their emotional intelligence (Badawy \& Magdy, 2015). In the life aspect of graduates, a study by Aziz \& Pangil (2017) and Pathak et al., (2018) yielded emotional intelligence assist in the school-to-work transition and employability. With strong emotional intelligence, graduates can strategize their future careers and easily thrive in demanding work environments that require them to stay strong. Thus, this paper hypothesised emotional intelligence is a factor that influences career adaptability.

$\mathrm{H} 2$ : There is an indirect influence of emotional intelligence on career adaptability.

\section{Self-perceived Competency Influences Career Adaptability}

Though employers are focusing on people with relevant skills, graduates should identify their abilities to succeed in the workplace. As self-perceived competencies are defined by Monteiro et al., (2020) as an individual's perception of one's skills, and ability to distinguish the actual and expected competencies in a related field. However, to become competent graduates, they have to be able to determine relevant industrial competencies and be aware of current and future industry demands that consist of the job skills and work competencies that enable them to perform a job (Akkermans et al., 2013).

As emphasised by the National Association of Colleges and Employers (2021) employers acquire specific skills from graduates such as self-development, good communication, critical thinking, the ability to distinguish equity and inclusion, leadership skills, professionalism, teamwork, and technological expertise. While summarised by Akkermans et al (2013) the career competencies are for better employment thrive, reflective, communicative, and behavioural. Those who can develop a relationship with their job and working conditions are more reflective in their performance of a job and meet task performance expectations. In terms of communication, organisations are looking for those who can speak at the right moment with ideas and exhibit the appropriate behaviour to fit the organization's corporate culture.

Recent studies show that career competencies and self-perceived competencies have a relationship with career adaptability (Akkermans et al., 2018; Dumulescu et al., 2015; Monteiro et al., 2020). In terms of employability, the previous study has shown career competencies are the predictor of preparing tertiary students' employability (Faizah, 2007; 
Hock \& Mandrinos, 2020; Hung \& Phuong, 2019; Kaur et al., 2008). Despite, the relationship, graduates' establishment on career adaptability through the acquisition of self-perceived competencies could increase graduates' employability and success in their future careers. Consequently, preparing graduates should not be limited to career competencies; rather, it should focus on career adaptability, which will directly affect employability (Coetzee \& Stoltz, 2015; Ismail, 2017). Thus, this paper describes self-perceived competencies as an individual self-awareness over the industrial demand of competencies for employability and hypothesis, $\mathrm{H} 3$ : There is an indirect influence of self-competencies on career adaptability.

\section{The Role of Mentoring as the Mediator on the Relationship between Personal Factors and Career Adaptability}

The extant literature suggests that mentoring mediates the influence of personal and career adaptability. Prior researcher(Hui et al., 2018; Kanten et al., 2017; Son, 2018) indicate that mentoring facilitates career adaptability and that mentoring implemented through organisational learning is effective in assisting graduates with their transition from university to the workplace (Wronka, 2018) and reaffirming a commitment to career advancement (Arora, 2020). Moreover, mentoring would assist graduates in acquiring conceptual and theoretical knowledge, thereby enabling them to cope with, adjust to, and prepare for unexpected work environments.

As defined by (Kram, 1983) mentoring is a one-on-one developmental relationship between senior and junior employees, inexperienced and new employees. There are two types of mentoring functions: psychological and career mentoring. The psychological practice facilitates the development of employees' confidence and work roles effectively. On the other hand, career mentoring is a psychological function integrated with roles as an advancement assistant to support employees in their career success. The mentor, as a role model, provides counselling and coaching as guidance and assistant in facilitating career enhancement as well as professional growth.

In addition, recent studies on mentoring show that mentoring significantly improves professional success, happiness and provides professional outcomes such as promotions, job mobility, salary increments, and professional commitment (Anafarta \& Apaydin, 2016; Bravo et al., 2017; Lapointe \& Vandenberghe, 2017). This professional mentoring acts as an effective career management tool to assist and guide protégés (Kanten et al., 2017; Lapointe \& Vandenberghe, 2017) in achieving a career outcome. Thus, a mentoring relationship between mentor and protégé could enhance performance (Carter \& Youssef-Morgan, 2019), career optimism (Kanten et al., 2017), emotional connection (Eby \& Robertson, 2019), career satisfaction, and career success (Anafarta \& Apaydin, 2016) through the establishment of career adaptability.

In this demanding working environment, mentoring's role as a role model, coach, and psychological counsellor (Lapointe \& Vandenberghe, 2017) would strengthen the relationship of individual and career adaptability. By utilising mentoring functions obtained through organisational and management support, mentoring can help regulate the relationship effect between protégé and mentor (Eby \& Robertson, 2019; Gyansah \& Guantan, 2018). Today's competitive labour market affects employees' ability to obtain the best job opportunities; however, for early-career employees, there is a career value associated with the length of employment in one organisation; therefore, the decision to stay or leave is somewhat dependent on their mentor, who may have an impact on their career future perspectives (Giraud et al., 2019). The interaction between the protégé (particularly the newly employed) 
and the mentor provides the mentor with direct control over job assignments, career guidance, and job security (Carter \& Youssef-Morgan, 2019; Lapointe \& Vandenberghe, 2017). Due to graduates' lower level of work maturity, mentoring activities can help mediate the individual by enhancing their personal resources and thus influencing their career adaptability. Thus, this paper's hypothesis.

$\mathrm{H} 4$ : The role of mentoring mediates the relationship between personal resources and career adaptability

\section{Framework of Study}

The extant literature on personal factors found in prior research determines the personal factors as a goal orientation (Creed et al., 2009; Yousefi et al., 2011), meaningfulness and emotional intelligence (Harry, 2017), proactive personality, and learning organization orientation (Zia et al., 2020) that have a direct relationship with career adaptability and selfdevelopment. Therefore, changes in society, technology, job demand, and job autonomy affect the indirect effect of personal variables on career adaptability and self-development. However, prior research measuring professional efficacy (Harry, 2017) and job autonomy (Zia et al., 2020) as a mediator did not indirectly relate personal variables to career adaptability and self-development.

Considering the findings of prior studies, mentoring activity is identified as a mediator in this paper to determine whether there is an indirect relationship between personal resources and career adaptability. As stated in the literature, mentoring positively affects people's career development, but there is a scarce empirical study on mediator linkage with career adaptability.

Since employers expect graduates to possess high adaptability, technical skills, and relevant competencies in relevant fields, organisation assistance through mentoring would enhance the expected demand. Thus, prior to graduation, a graduate's personal strength must be developed, and organisation support will assist graduates who are newly employed in adjusting to their new work environment.

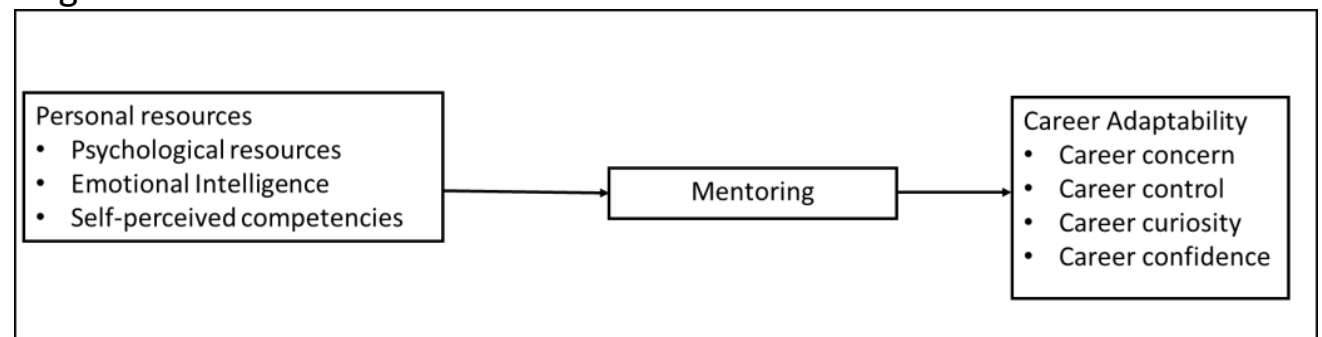

Figure 1. Personal resources influence career adaptability that is mediated by mentoring.

\section{Theory and Study Context}

This paper employ career construction theory to examine the personal resources' influence on career adaptability. Individual adaptability was emphasised by establishing their willingness to adapt and skill enhancement in order to lead their own lives and identities, according to career construction theory (Hartung \& Cadaret, 2017). The individual life experience through life roles in school, community, and occupational settings would assist in the working transition and reflect on pursuing career goals. Additionally, the theory asserts interaction between personal and environmental is important in determining an individual's life adjustment (Savickas \& Porfeli, 2012). Henceforth, in the dynamic working environment, 
interpersonal interaction integrated with organisational culture led individuals to view their career paths.

Therefore, career construction theory is appropriate as a framework for establishing graduates' career adaptability. By adopting the career adaptability concept, graduates are able to develop their self-image, acknowledging their self-competencies through life experiences and cultural discourse. In addition, acknowledging their self-strengths, they can explore potential career paths, develop and practice the competencies necessary to thrive in the occupation, and self-regulate in response to unexpected work environments.

Since university to working life is a complex transition, graduates are expected to be self-adaptive to ease in unexpected working conditions (Son, 2018). The ability to thrive in a work environment is developed through readiness and preparation to deal with work-related traumas (Ramos \& Lopez, 2018). Accordingly, individuals that possess personal strength positively perceive the facilitation of the career construction process. Additionally, a holistic mentoring experience within an organisation assists graduates in developing a high degree of career adaptability, allowing them to feel at ease in their new life path.

\section{Conclusion and Implication}

There is an emerging scope of career adaptability to be discussed. The topic is relevant for individual career self-construction. Through life-theme experience and self-capabilities, people can predict future growth to remain valuable. In this challenging labour market, traditional career movements are no longer effective organisational control, so people must consider their strengths. In the sense of graduates, strengthening their self-control and sense of personal worth could help them increase their employability rate. As a result, collaboration among industry practitioners, academia, and graduates in determining the industrial competencies demanded would reduce the rate of unemployment, job dissatisfaction, and intention to leave among graduates in their new jobs. They can articulate, strengthen, and determine the value of coping with a situation and the organization's role in assisting them in navigating career adaptability. Additionally, this paper could also contribute to the body of knowledge and educate readers about the critical nature of career adaptability.

\section{References}

Abd Rahman, N. H., Ismail, S., Ridzuan, A. R., \& Abd Samad, K. (2020). The Issue of Graduate Unemployment in Malaysia: Post Covid-19. International Journal of Academic Research in Business and Social Sciences, 10(10). https://doi.org/10.6007/ijarbss/v10-i10/7843

Abdul Wahed, J. (2017). Rethinking our education. New Straits Times. https://www.nst.com.my/opinion/columnists/2017/05/235683/rethinking-oureducation

Akkermans, J., Brenninkmeijer, V., Huibers, M., \& Blonk, R. W. B. (2013). Competencies for the Contemporary Career: Development and Preliminary Validation of the Career Competencies Questionnaire. Journal of Career Development, 40(3), 245-267. https://doi.org/10.1177/0894845312467501

Akkermans, J., Paradniké, K., van der Heijden, B. I. J. M., \& de Vos, A. (2018). The best of both worlds: The role of career adaptability and career competencies in students' well-being and performance. Frontiers in Psychology, 9(SEP).

https://doi.org/10.3389/fpsyg.2018.01678

Anafarta, A., \& Apaydin, C. (2016). The Effect of Faculty Mentoring on Career Success and Career Satisfaction. International Education Studies, 9(6), 22. 
https://doi.org/10.5539/ies.v9n6p22

Anastasiou, S. (2020). The moderating effect of age on preschool teachers' trait emotional intelligence in Greece and implications for preschool human resources management. International Journal of Education and Practice, 8(1).

https://doi.org/10.18488/journal.61.2020.81.26.36

Arora, R. (2020). Mediating role of mentoring functions on linking personality and occupational commitment in Indian organizations. Human Resource Development International, 23(3), 283-308. https://doi.org/10.1080/13678868.2020.1727218

Asif Kiyani, Muhammad Haroon, Asim Sohail Liaqat, Mohamad Arif Khattak, Syed Junaid Ahmed Bukhari, \& Rabia Asad. (2011). Emotional intelligence and employee participation in decision-making. African Journal of Business Management, 5(12), 47754781. https://doi.org/10.5897/AJBM10.808

Avey, J. B., Luthans, F., Smith, R. M., \& Palmer, N. F. (2010). Impact of positive psychological capital on employee well-being over time. Journal of Occupational Health Psychology, 15(1), 17-28. https://doi.org/10.1037/a0016998

Aziz, A., \& Pangil, F. (2017). Moderating Effect of Emotional Intelligence on the Relationship between Personality Traits and Employability. Saudi Journal of Humanities and Social Sciences, 2(2).

Badawy, T. A. el, \& Magdy, M. M. (2015). Assessing the Impact of Emotional Intelligence on Job Satisfaction: An Empirical Study on Faculty Members with Respect to Gender and Age. International Business Research, 8(3). https://doi.org/10.5539/ibr.v8n3p67

Bandura, A. (1994). Encyclopedia of mental health (Vol. 4). Academic Press. http://www.des.emory.edu/mfp/BanEncy.html

Bravo, J., Seibert, S. E., Kraimer, M. L., Wayne, S. J., \& Liden, R. C. (2017). Measuring Career Orientations in the Era of the Boundaryless Career. Journal of Career Assessment, 25(3), 502-525. https://doi.org/10.1177/1069072715616107

Buyukgoze-Kavas, A. (2016). Predicting Career Adaptability From Positive Psychological Traits. Career Development Quarterly, 64(2), 114-125. https://doi.org/10.1002/cdq.12045

Carter, J. W., \& Youssef-Morgan, C. M. (2019). The positive psychology of mentoring: A longitudinal analysis of psychological capital development and performance in a formal mentoring program. Human Resource Development Quarterly, 30(3), 383-405. https://doi.org/10.1002/hrdq.21348

Chartered Institute of Personnel and Development. (2019). The future of talent in Malaysia 2035. www.hrdf.com.my

Chen, H., Fang, T., Liu, F., Pang, L., Wen, Y., Chen, S., \& Gu, X. (2020). Career adaptability research: A literature review with scientific knowledge mapping in web of science. In International Journal of Environmental Research and Public Health (Vol. 17, Issue 16, pp. 1-21). MDPI AG. https://doi.org/10.3390/ijerph17165986

Cheong, K. C., Hill, C., Fernandez-Chung, R., \& Leong, Y. C. (2016). Employing the 'unemployable': employer perceptions of Malaysian graduates. Studies in Higher Education, 41(12), 2253-2270. https://doi.org/10.1080/03075079.2015.1034260

Coetzee, M., Ferreira, N., \& Shunmugum, C. (2017). Psychological career resources, career adaptability, and work engagement of generational cohorts in the media industry. https://doi.org/10.4102/sajhrm

Coetzee, M., \& Harry, N. (2014). Emotional intelligence as a predictor of employees' career adaptability. Journal of Vocational Behavior, 84(1).

https://doi.org/10.1016/j.jvb.2013.09.001 
Coetzee, M., \& Stoltz, E. (2015). Employees' satisfaction with retention factors: Exploring the role of career adaptability. Journal of Vocational Behavior, 89, 83-91. https://doi.org/10.1016/j.jvb.2015.04.012

Creed, P. A., Fallon, T., \& Hood, M. (2009). The relationship between career adaptability, person and situation variables, and career concerns in young adults. Journal of Vocational Behavior, 74(2), 219-229. https://doi.org/10.1016/j.jvb.2008.12.004

Dian, H. M. I., \& Zaidi, M. M. (2016). Youth Unemployment in Malaysia: Developments and Policy Considerations. In Annual Report.

Dumulescu, D., Balazsi, R., \& Opre, A. (2015). Calling and Career Competencies among Romanian Students: The Mediating Role of Career Adaptability. Procedia - Social and Behavioral Sciences, 209, 25-32. https://doi.org/10.1016/j.sbspro.2015.11.223

Eby, L. T., \& Robertson, M. M. (2019). Annual Review of Organizational Psychology and Organizational Behavior The Psychology of Workplace Mentoring Relationships. https://doi.org/10.1146/annurev-orgpsych-012119

Edwin, A. (2020). The Factors that Influence Intention among Aviation Maintenance Personnel in Kota Kinabalu International Airport Sabah. Malaysia Journal of Business and Economics, 7(2), 73-97.

Eryilmaz, A., SATICI Assist, B., \& Engin DENIZ, M. (2020). A Model of Career Adaptability for Teachers: Emotional Intelligence, Goal Setting and Striving for Goals. International Online Journal of Primary Education, 9(1). www.iojpe.orgOrcid:https://orcid.org/00000001-9301-59460rcid:https://orcid.org/0000-0003-2161-

782XOrcid:https://orcid.org/0000-0002-7930-3121

Faizah, Y. (2007). Youth Employment and Employability in Malaysia. Malaysian Youth Report.

Fang, W., Zhang, Y., Mei, J., Chai, X., \& Fan, X. (2018). Relationships between optimism, educational environment, career adaptability and career motivation in nursing undergraduates: A cross-sectional study. Nurse Education Today, 68, 33-39. https://doi.org/10.1016/j.nedt.2018.05.025

Fawehinmi, O. O., \& Yahya, K. K. (2018). Investigating the Linkage Between Proactive Personality and Social Support on Career Adaptability Amidst Undergraduate Students. Journal of Business and Social Review in Emerging Economies, 4(1), 81-92. https://doi.org/10.26710/jbsee.v4i1.370

Fiori, M., Bollmann, G., \& Rossier, J. (2015). Exploring the path through which career adaptability increases job satisfaction and lowers job stress: The role of affect. Journal of Vocational Behavior, 91, 113-121. https://doi.org/10.1016/j.jvb.2015.08.010

Francisco, I. F. S., \& Castano, M. C. N. (2020). The Impact of Career Adaptability to the Job Search Strategies of Graduate Students in NCR. GATR Journal of Management and Marketing Review, 5(1), 41-50. https://doi.org/10.35609/jmmr.2020.5.1(4)

Giraud, L., Bernard, A., \& Trinchera, L. (2019). Early career values and individual factors of objective career success: The case of the French business graduates. Career Development International, 24(4), 350-382. https://doi.org/10.1108/CDI-06-20170093

Green, Z. A., Noor, U., \& Hashemi, M. N. (2020). Furthering Proactivity and Career Adaptability Among University Students: Test of Intervention. Journal of Career Assessment, 28(3), 402-424. https://doi.org/10.1177/1069072719870739

Guan, M., Capezio, A., Restubog, S. L. D., Read, S., Lajom, J. A. L., \& Li, M. (2016). The role of traditionality in the relationships among parental support, career decision-making self- 
efficacy and career adaptability. Journal of Vocational Behavior, 94, 114-123. https://doi.org/10.1016/j.jvb.2016.02.018

Gyansah, S. T., \& Guantan, H. K. (2018). Career Development in Organizations: Placing the Organization and the Employee on the Same Pedestal to Enhance Maximum Productivity. In European Journal of Business and Management www.iiste.org ISSN (Vol. 10, Issue 14). Online. www.iiste.org

Haibo, Y., Xiaoyu, G., Xiaoming, Z., \& Zhijin, H. (2018). Career Adaptability With or Without Career Identity: How Career Adaptability Leads to Organizational Success and Individual Career Success? Journal of Career Assessment, 26(4), 717-731. https://doi.org/10.1177/1069072717727454

Harry, N. (2017). Personal factors and career adaptability in a call centre work environment: The mediating effects of professional efficacy. Journal of Psychology in Africa, 27(4), 356-361. https://doi.org/10.1080/14330237.2017.1347758

Hartung, P. J., \& Cadaret, M. C. (2017). Career adaptability: Changing self and situation for satisfaction and success. In Psychology of Career Adaptability, Employability and Resilience (pp. 15-28). Springer International Publishing. https://doi.org/10.1007/9783-319-66954-0_2

Harvard Business Review. (2019). The New Perspective on Work Changing Attitudes and Opinions of Young Professionals about Work and the Workplace.

Heang, L. T., Ching, L. C., Mee, L. Y., \& Huei, C. T. (2019). University Education and Employment Challenges: An Evaluation of Fresh Accounting Graduates in Malaysia. International Journal of Academic Research in Business and Social Sciences, 9(9). https://doi.org/10.6007/ijarbss/v9-i9/6396

Hock, R. L. T., \& Mandrinos, S. (2020). Students' Career Readiness and Employability /. Swinburn University of Technology. https://www.swinburne.edu.my/campusbeyond/students-career-readiness-employability.php

Hui, T., Yuen, M., \& Chen, G. (2018). Career Adaptability, Self-Esteem, and Social Support Among Hong Kong University Students. Career Development Quarterly, 66(2), 94-106. https://doi.org/10.1002/cdq.12118

Hung, L. T., \& Phuong, P. T. A. (2019). Student Skills and Employability: A Study from Students' Perspective. VNU Journal of Science: Education Research. https://doi.org/10.25073/2588-1159/vnuer.4220

Ibrahim, A.-J., Binti, S. N., Anuar, S., Bin, A. A., \& Suhaimi, A. (2021). The Impact of Career Adaptability and Social Support on Job Search Self-Efficacy: A Case Study in Malaysia. Aissa MOSBAH / Journal of Asian Finance, 8(6), 515-0524.

https://doi.org/10.13106/jafeb.2021.vol8.no6.0515

Ilyana, A., \& Siti Raba'ah, H. (2020). Predicting career adaptability of fresh graduates through personal factors. European Journal of Training and Development. https://doi.org/10.1108/EJTD-02-2020-0023

Ismail, S. (2017). Graduate employability capacities, self-esteem, and career adaptability among South African young adults. SA Journal of Industrial Psychology, 43(1). https://doi.org/10.4102/sajip.v43i0.1396

Jameson, A., Carthy, A., McGuinness, C., \& McSweeney, F. (2016). Emotional Intelligence and Graduates - Employers' Perspectives. Procedia - Social and Behavioral Sciences, 228, 515-522. https://doi.org/10.1016/j.sbspro.2016.07.079

Jiang, Z. (2017). Proactive personality and career adaptability: The role of thriving at work. Journal of Vocational Behavior, 98, 85-97. https://doi.org/10.1016/j.jvb.2016.10.003 
Kanten, S., Kanten, P., \& Ulker, F. (2017). The Effects of Mentoring Functions on Career Adaptabilities and Career Self-Efficacy: The Role of Career Optimism. European Journal of Multidiscipline Studies, 6(2), 259-272. https://doi.org/10.26417/ejms.v6i2.p259-272

Kashmoola, B., Ahmad, F., \& Kheng, Y. K. (2017). Review on Job Satisfaction, Intention to Leave and Corporate Entrepreneurial Characteristics in United Arab Emirates' Construction Firms. International Journal of Emerging Research in Management and Technology, 6(10), 105. https://doi.org/10.23956/ijermt.v6i10.74

Kaur, G., Singh, G., Kaur, S., \& Singh, G. (2008). Malaysian Graduates Employability Skills. UNITAR E-JOURNAL, 4(1).

Kram, K. E. (1983). Mentoring at Work: Developmental Relationships in Organisational Life. Academy of Management Journal, 26, 1986.

Lapointe, É., \& Vandenberghe, C. (2017). Supervisory mentoring and employee affective commitment and turnover: The critical role of contextual factors. Journal of Vocational Behavior, 98, 98-107. https://doi.org/10.1016/j.jvb.2016.10.004

Le, K. K., Hamzah, S. R., \& Omar, Z. (2019). Conceptualising Personal Resources on Career Adaptability. International Journal of Academic Research in Business and Social Sciences, 9(9). https://doi.org/10.6007/ijarbss/v9-i9/6378

Lumanta, K. (2020). Effective workplace adaptability for a post-COVID world / Michael Page. https://www.michaelpage.com.au/advice/management-advice/leadership/effectiveworkplace-adaptability-post-covid-world

Luthans, F., Youssef, C. M., \& Avolio, B. J. (2007). Psychological Capital: Developing the Human Competitive Edge. Oxford University Press.

Mahathir, M., \& Vethasalam, R. (2021). The education system is outdated, needs reform, says Dr Mahathir. The Malaysian Insight. https://www.themalaysianinsight.com/s/303014

McKenna, J. (2021). Why Career Adaptability Is Your Best Strategy for Success. Rusher Roger Recruiters. https://www.rusherrogers.com.au/why-career-adaptability-is-your-beststrategy-for-success/

Merino-Tejedor, E., Hontangas, P. M., \& Petrides, K. v. (2018). Career Adaptability Mediates the Effect of Trait Emotional Intelligence on Academic Engagement. Revista de Psicodidactica, 23(2), 77-85. https://doi.org/10.1016/j.psicod.2017.10.001

MichaelPage. (2019). Emotional intelligence - the new skills gap / Michael Page. https://www.michaelpage.co.uk/news/media-releases/emotional-intelligence\%E2\%80\%93-new-skills-gap

Ministry of Higher Education, M. (2020). Statistik PT 2020 - 09. Bab 7 - Graduate Tracer Studies.

Ministry of Human Resources, M. (2020). Penjana Kerjaya \& MY Future Jobs.

Mittal, S. (2020). Ability-based emotional intelligence and career adaptability: role in the jobsearch success of university students. Higher Education, Skills and Work-Based Learning, 11(2), 454-470. https://doi.org/10.1108/HESWBL-10-2019-0145

Monster.Inc. (2020). \#MyFirstJob. https://www.monster.com.my/careeradvice/research.html

Monteiro, S., Almeida, L., \& Aracil, A. G. (2016). Graduates' perceptions of competencies and preparation for labour market transition: The effect of gender and work experience during higher education. Higher Education, Skills and Work-Based Learning, 6(2), 208220. https://doi.org/10.1108/HESWBL-09-2015-0048 
Monteiro, S., Ferreira, J. A., \& Almeida, S. L. (2020). Self-perceived competency and selfperceived employability in higher education: the mediating role of career adaptability. Journal of Further and Higher Education, 44(3), 408-422. https://doi.org/10.1080/0309877X.2018.1542669

Monteiro, S., Taveira, M. do C., \& Almeida, L. (2019). Career adaptability and university-towork transition: Effects on graduates' employment status. Education and Training, 61(9), 1187-1199. https://doi.org/10.1108/ET-10-2018-0206

Mumu, J. R., Tahmid, T., \& Azad, M. A. K. (2021). Job satisfaction and intention to quit: A bibliometric review of work-family conflict and research agenda. Applied Nursing Research, 59. https://doi.org/10.1016/j.apnr.2020.151334

Mustapa, M. (2020, October). Special Report: 'We need to up the ante' / The Edge Markets. The Edge Malaysia. https://www.theedgemarkets.com/article/special-report-we-needante

National Association of Colleges and Employers. (2021). Competencies for Career-Ready Workforce.

Nilforooshan, P., \& Salimi, S. (2016). Career adaptability as a mediator between personality and career engagement. Journal of Vocational Behavior, 94, 1-10. https://doi.org/10.1016/j.jvb.2016.02.010

Nooriah, Y., \& Zakiyah, J. (2015). Graduate employability and preparedness: A case study of University of Malaysia Perlis (UNIMAP), Malaysia. Malaysian Journal of Society and Space, 11(11), 129-143.

Othman, R., Kamal, N. M., Alias, N. E., Ismail, S., \& Sahiq, A. N. Md. (2018). Positive Psychological Traits and Career Adaptability among Millennials. International Journal of Academic Research in Business and Social Sciences, 8(9). https://doi.org/10.6007/ijarbss/v8-i9/4706

Parmentier, M., Pirsoul, T., \& Nils, F. (2019). Examining the impact of emotional intelligence on career adaptability: A two-wave cross-lagged study. Personality and Individual Differences, 151. https://doi.org/10.1016/j.paid.2019.05.052

Pathak, A., Shankar, S., \& Tewari, V. (2018). Impact of Emotional Intelligence on employability of IT professionals. Management Insight - The Journal of Incisive Analysers, 14(1). https://doi.org/10.21844/mijia.14.01.4

Puteh, F., Kaliannan, M., \& Alam, N. (2015). Assessing Gen Y Impact on Organizational Performance: An Analysis from Top Management Perspective. In Journal of Administrative Science (Vol. 12).

PwC Malaysia. (2021a). 24th Annual Global CEO Survey. 24th Annual Global CEO Survey Malaysia Findings. https://www.pwc.com/gx/en/ceo-agenda/ceosurvey/2021.html

PwC Malaysia. (2021b). A leadership agenda to take on tomorrow. PwC's 24th CEO Survey. https://www.pwc.com/my/en/publications/2021/24th-ceo-survey-malaysiafindings.html

Rozman, M., Grinkevich, A., \& Tominc, P. (2019). Occupational Stress, Symptoms of Burnout in the Workplace and Work Satisfaction of the Age-diverse Employees. In Organizacija (Vol. 52, Issue 1, pp. 46-59). Sciendo. https://doi.org/10.2478/orga-2019-0005

Safavi, H. P., \& Bouzari, M. (2019). The association of psychological capital, career adaptability and career competency among hotel frontline employees. Tourism Management Perspectives, 30, 65-74. https://doi.org/10.1016/j.tmp.2019.02.001 
Safavi, H. P., \& Karatepe, O. M. (2018). High-performance work practices and hotel employee outcomes: The mediating role of career adaptability. International Journal of Contemporary Hospitality Management, 30(2), 1112-1133. https://doi.org/10.1108/IJCHM-07-2016-0367

Salovey, P., \& Mayer, J. D. (1990). Emotional intelligence. Educational Leadership, 9(3), 185211. https://doi.org/10.2190/dugg-p24e-52wk-6cdg

Santilli, S., Marcionetti, J., Rochat, S., Rossier, J., \& Nota, L. (2017). Career Adaptability, Hope, Optimism, and Life Satisfaction in Italian and Swiss Adolescents. Journal of Career Development, 44(1), 62-76. https://doi.org/10.1177/0894845316633793

Savickas, M. L., \& Porfeli, E. J. (2012). Career Adapt-Abilities Scale: Construction, reliability, and measurement equivalence across 13 countries. Journal of Vocational Behavior, 80(3), 661-673. https://doi.org/10.1016/j.jvb.2012.01.011

Savickas, M. L., \& Savickas, S. (2016). Vocational psychology, overview. In The Curated Reference Collection in Neuroscience and Biobehavioral Psychology (pp. 460-470). Elsevier Science Ltd. https://doi.org/10.1016/B978-0-12-809324-5.05746-1

Savickas, Mark. L. (2013). Career Construction Theory and Practice. In Praise for Career Development and Counseling: Putting Theory and Research to Work, Second Edition (pp. 147-183).

Serrat, O. (2017). Understanding and Developing Emotional Intelligence. In Knowledge solutions: Tools, Methods, and Approaches to Drive Organizational Performance (pp. 329-341). Springer Open.

Shabeer, S., Mohammed, S. J., Jawahar, I. M. “Jim,” \& Bilal, A. R. (2019). The Mediating Influence of Fit Perceptions in the Relationship Between Career Adaptability and Job Content and Hierarchical Plateaus. Journal of Career Development, 46(3), 332-345. https://doi.org/10.1177/0894845318763960

Shabir, M., Abrar, M., Baig, S. A., \& Javed, M. (2014). The Contribution of Workplace Incivility and Psychological Capital toward Job Stress. International Journal of Human Resource Studies, 4(2), 1. https://doi.org/10.5296/ijhrs.v4i2.5786

Shamsuddin, B. (2020). Whose Problem is Graduate Unemployment in Malaysia? Experts Weigh in. MalayMail. https://www.malaymail.com/news/malaysia/2020/01/13/whose-problem-isgraduate-unemployment-in-malaysia-experts-weigh-in/1827627

Shamsuddin, B., \& Christina, C. (2020). Skills are Key, says MEF. The Star. https://www.thestar.com.my/news/education/2020/09/20/skills-are-key-says-mef

Sharfras Navas, M. A., \& Vijayakumar, M. (2018). Emotional Intelligence: A Review of Emotional Intelligence Effect on Organizational Commitment, Job Satisfaction and Job Stress. International Journal of Advanced Scientific Research \& Development (IJASRD), 5(6). https://doi.org/10.26836/ijasrd/2018/v5/i6/50602

Shen, X. L., Li, Y. J., Sun, Y., \& Zhou, Y. (2018). Person-environment fit, commitment, and customer contribution in the online brand community: A nonlinear model. Journal of Business Research, 85, 117-126. https://doi.org/10.1016/j.jbusres.2017.12.007

Shin, Y. J., \& Lee, J. Y. (2019). Self-Focused Attention and Career Anxiety: The Mediating Role of Career Adaptability. Career Development Quarterly, 67(2), 110-125. https://doi.org/10.1002/cdq.12175

Shipley, N. L., Jo Jackson, M., Larisa Segrest, S., \& St Petersburg, F. (2010). The effects of emotional intelligence, age, work experience, and academic performance. Research in Higher Education Journal. 
Son, S. J. (2018). The more reflective, the more career-adaptable: A two-wave mediation and moderation analysis. Journal of Vocational Behavior, 109, 44-53. https://doi.org/10.1016/j.jvb.2018.09.004

Sony, M., \& Mekoth, N. (2016). The relationship between emotional intelligence, frontline employee adaptability, job satisfaction and job performance. Journal of Retailing and Consumer Services, 30, 20-32. https://doi.org/10.1016/j.jretconser.2015.12.003

TalentCorp Malaysia. (2017). Visioning Malaysia's Future Of Work: Visioning Malaysia's Future of Work: A Framework for Action Contents. https://www.talentcorp.com.my/clients/TalentCorp_2016_7A6571AE-D9D0-4175B35D-

99EC514F2D24/contentms/img/publication/TalentCorp_Visioning\%20Malaysias\%20Fu ture\%20of\%20Work_2017.pdf

Urbanaviciute, I., Udayar, S., \& Rossier, J. (2019). Career adaptability and employee well-being over a two-year period: Investigating cross-lagged effects and their boundary conditions. Journal of Vocational Behavior, 111, 74-90.

https://doi.org/10.1016/j.jvb.2018.10.013

Wong, C.-S., \& Law, K. S. (2002). The effects of leader and follower emotional intelligence on performance and attitude: An exploratory study. The Leadership Quarterly 13, 243-274.

World Bank. (2021). Overview: Development news, research, data / World Bank. Malaysia@worldbank.Org. https://www.worldbank.org/en/country/malaysia/overview\#1

Wronka, M. (2018). Mentoring in the concept of the learning organization in higher education - empirical research / Mentoring w koncepcji organizacji uczącej się szkoły wyższej w świetle badań empirycznych. Management, 17(1), 273-290. https://doi.org/10.2478/manment-2013-0019

Yang, X., Feng, Y., Meng, Y., \& Qiu, Y. (2019). Career adaptability, work engagement, and employee well-being among chinese employees: The role of Guanxi. Frontiers in Psychology, 10(MAY). https://doi.org/10.3389/fpsyg.2019.01029

Yen, H.-C., Cheng, J.-W., Hsu, C.-T., \& Yen, K.-C. (2019). How career adaptability can enhance career satisfaction: Exploring the mediating role of person-job fit. Journal of Management \& Organization, 1-18. https://doi.org/10.1017/jmo.2019.75

Yousefi, Z., Abedi, M., Baghban, I., Eatemadi, O., \& Abedi, A. (2011). Personal and Situational Variables, and Career Concerns: Predicting Career Adaptability in Young Adults. The Spanish Journal of Psychology, 14(1), 263-271. https://doi.org/10.5209/rev_sjop.2011.v14.n1.23

Zia, M. Q., Naveed, M., Bashir, M. A., \& Shamsi, A. F. (2020). The interaction of situational factors on individual factors and self-development. European Journal of Training and Development, 44(4-5), 509-530. https://doi.org/10.1108/EJTD-10-2019-0172

Zuraini, A. K. (2020). Dilema Isu Pengangguran Belia di Malaysia. 